\title{
Katarzyna Błażkiewicz-Skuza
}

Uniwersytet Ekonomiczny w Katowicach

e-mail: katarzyna.blazkiewicz@edu.uekat.pl

\section{SYSTEM OPODATKOWANIA NIERUCHOMOŚCI A WPLYWY BUDŻETOWE Z TYTULU PODATKU OD NIERUCHOMOŚCI W PAŃSTWACH CZLONKOWSKICH UNII EUROPEJSKIEJ}

\section{PROPERTY TAXATION SYSTEM VS. BUDGET REVENUES DUE TO PROPERTY TAX IN THE MEMBER STATES OF THE EUROPEAN UNION}

DOI: $10.15611 / \mathrm{pn} .2018 .528 .01$

JEL Classification: A10, H20, K11

Streszczenie: Brak harmonizacji, ujednoliconych standardów odnoszących się do stosowanych systemów opodatkowania nieruchomości stwarza państwom członkowskim Unii Europejskiej możliwość wyboru systemu opodatkowania. Celem artykułu jest analiza porównawcza systemów opodatkowania nieruchomości, jakie są stosowane w państwach członkowskich Unii Europejskiej (wartościowy, powierzchniowy oraz mieszany). Ponadto zbadano wpływy budżetowe z tytułu podatku od nieruchomości w zależności od przyjętego systemu. Podjęto również próbę analizy wydajności fiskalnej i stabilności tychże wpływów. Osiągnięciu celu posłużyły studia literatury oraz analiza danych statystycznych. Wnioski z przeprowadzonych badań uprawniają do stwierdzenia, iż w państwach członkowskich UE dominuje system wartościowy opodatkowania majątku nieruchomego, aczkolwiek każde z państw stosuje elementy wyróżniające. Ponadto wielkość wpływów z tytułu podatku od nieruchomości zależy od stosowanego przez państwo systemu opodatkowania.

Słowa kluczowe: podatek od nieruchomości, podatek katastralny, wpływy budżetowe.

Summary: Lack of harmonization, unified standards relating to used property taxation systems creates the alternative for Member States of the European Union in the selection of the taxation system. The article presents property taxation systems used in the Member States of the European Union (ad valorem, surface and mixed), then examines bugdet proeeds due to property tax depending on the system adopted. A trial was also made to analyze fiscal efficiency and the stability of these proceeds. Goal fulfillment has served literature studies and the analysis of statistical data.

Keywords: property tax, cadastral tax, budget revenues. 


\section{Wstęp}

Podatek od nieruchomości stosowany jest w ponad 130 krajach świata i jest jednym z najbardziej popularnych podatków majątkowych w państwach członkowskich Organizacji Współpracy Gospodarczej i Rozwoju (OECD) [Marona 2006, s. 115].

Podatek od nieruchomości, będący elementem systemu opodatkowania majątku nieruchomego, pełni elementarną funkcję, jaką jest generowanie dochodu do budżetu. Z fiskalnego punktu widzenia uzyskiwany dochód jest niezbędny, by móc finansować potrzeby publiczne, takie jak edukacja, bezpieczeństwo, opieka zdrowotna itp. Celem artykułu jest porównawcza prezentacja rozwiązań w zakresie opodatkowania nieruchomości stosowanych w państwach członkowskich Unii Europejskiej ${ }^{1}$ oraz ocena ich znaczenia fiskalnego w latach 2010-2015. Realizacji celu posłużyły studia literatury oraz analiza danych statystycznych.

\section{Systemy opodatkowania nieruchomości}

Podatki majątkowe, które w głównej mierze są podatkami lokalnymi, pozostają poza płaszczyzną formalnej harmonizacji unijnej [Famulska (red.) 2009, s. 40]. W konsekwencji w państwach członkowskich UE zauważalny jest brak ujednoliconego modelu systemu opodatkowania nieruchomości. Brak międzynarodowych standardów i reguł powoduje występowanie różnic $\mathrm{w}$ definiowaniu systemów opodatkowania nieruchomości w zależności od państwa. Najogólniej wyróżnia się dwa elementarne systemy opodatkowania majątku nieruchomego. Najczęściej stosowany jest system wartościowy, zwany także katastralnym bądź ad valorem, czyli od wartości. Drugi system opodatkowania, już coraz rzadziej stosowany, za podstawę przyjmuje powierzchnię nieruchomości. System ten obowiązuje obecnie w Polsce w odniesieniu do gruntów i budynków.

Systemy opodatkowania nieruchomości są zróżnicowane, jeśli brać pod uwagę nie tylko określenie podstawy opodatkowania, lecz także wysokość stawek, ulgi podatkowe, zwolnienia oraz częstotliwość uiszczania daniny. Niemniej jednak należy zauważyć, iż próba analizowania systemów opodatkowania opiera się na szeroko pojętej definicji władania nieruchomością, w której podmiotami władającymi są: najemca, dzierżawca, użytkownik wieczysty oraz właściciel [Etel 2003, s. 7-8].

Systemy wartościowe stosowane w państwach członkowskich UE są uwarunkowane ich sytuacją historyczno-społeczną. Istnieją wszakże charakterystyczne cechy wspólne współczesnych systemów opodatkowania nieruchomości (rys. 1): wartość przybliżona, która jest określana na podstawie wyceny masowej wartości nieruchomości reprezentatywnych, wartość czynszowa ustalana na podstawie cen wynajmu nieruchomości, wartość rynkowa ustalana na podstawie cen sprzedaży oraz wartość gruntu, która jest określana według cen transakcyjnych gruntu [Głuszak, Marona

\footnotetext{
${ }^{1} \mathrm{~W}$ badaniach uwzględniono także Wielką Brytanię.
} 
2015]. Pomimo że warianty wartościowe opodatkowania mają wspólny mianownik: opierają się na wartości nieruchomości, to zasadniczym elementem różniącym jest przyjęta definicja wartości nieruchomości i jej ujęcie oraz metoda szacowania. System katastralny jest dominującym modelem stosowanym w państwach członkowskich UE (21 państw).
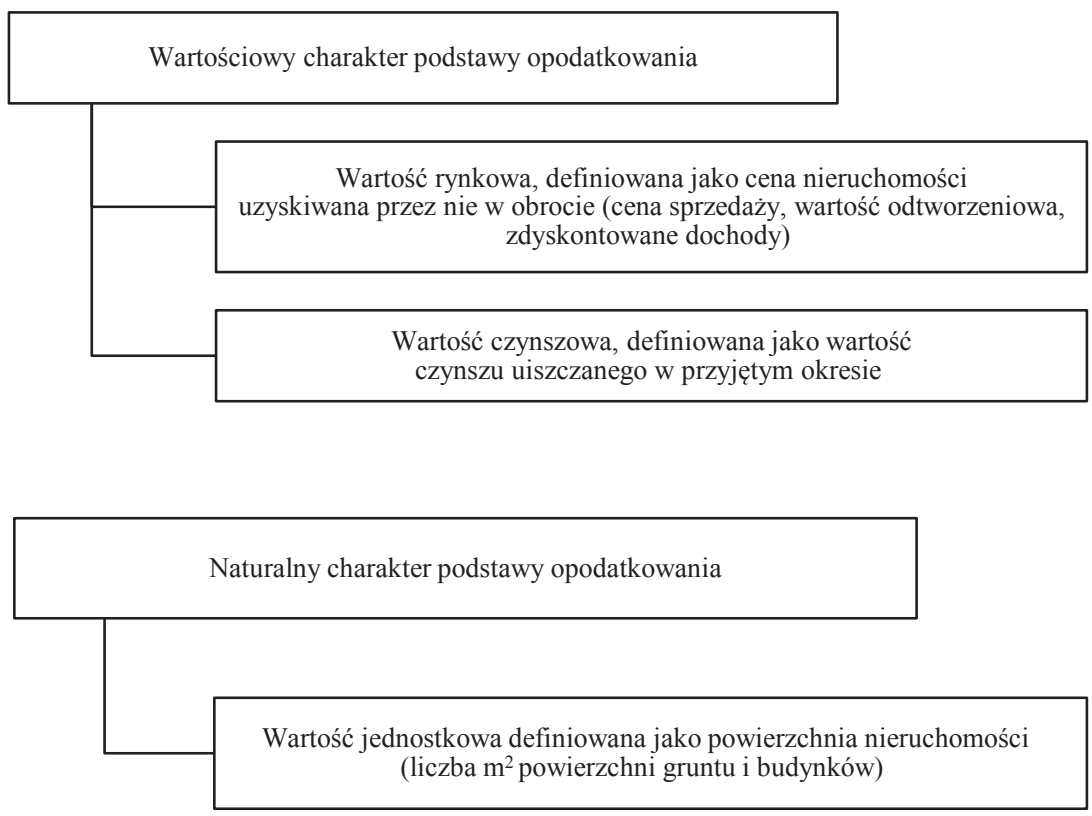

Rys. 1. Podstawa obliczania podatku od nieruchomości

Źródło: [Felis 2013, s. 2].

Systemy powierzchniowe funkcjonują głównie w krajach, gdzie jeszcze do niedawna gospodarka nie funkcjonowała w trybie wolnorynkowym. To państwa Europy Środkowej i Wschodniej: Polska, Bułgaria, Czechy i Słowacja. Kryterium decydującym o wysokości podatku od nieruchomości jest powierzchnia. W odróżnieniu do wartości nieruchomości, jej powierzchnia jest znacznie łatwiejsza do ustalenia i zweryfikowania, a przede wszystkim niezmienna w czasie.

W Polsce temat podatku katastralnego jest bardzo kontrowersyjny, a debata na ten temat trwa już ponad 20 lat. Jedną z największych obaw przed wprowadzeniem opodatkowania wartości majątku nieruchomego jest znaczny wzrost wysokości obciążenia podatkowego, jaki będzie ciążył na podatnikach. Należy tutaj jednak wspomnieć, że kwestia ta zależy od ustalenia wysokości stawki podatkowej i samej definicji wartości. Niemniej do obsługi systemu wartościowego niezbędne jest stworzenie systemu informacji o nieruchomościach, przeprowadzenie powszechnej taksacji, zatrudnienie wykwalifikowanej kadry oraz bieżąca aktualizacja informacji 
zawartych w katastrze, a co za tym idzie, poniesienie znacznie wyższych kosztów wdrożenia systemu.

Niewątpliwym atutem systemów powierzchniowych są ponoszone koszty realizacji opodatkowania. Mechanizm ustalania stawek podatkowych, jak i pobór samej daniny nie wymagają rozbudowanych i kosztownych systemów czy wyspecjalizowanego personelu. Podatek od powierzchni zwykle wymaga jedynie przemnożenia stawki podatkowej przez liczbę $\mathrm{m}^{2}$ danej nieruchomości.

W systemach powierzchniowych można wyróżnić cechy systemów wartościowych. Przykładem jest polski system, gdzie w przypadku budowli podstawą opodatkowania jest jej wartość zakładana w celu amortyzacji środków trwałych [Etel 2003].

Trzecim wariantem jest system mieszany, łączący cechy obu systemów zdefiniowanych wcześniej systemów, który jest stosowany na Węgrzech i w Rumunii [Felis 2013].

\section{Charakterystyka systemów opodatkowania nieruchomości w wybranych państwach czlonkowskich UE}

Jak już wspomniano, najpopularniejszym systemem opodatkowania nieruchomości w państwach członkowskich UE jest system wartościowy. W celu przybliżenia charakterystyki i dysproporcji pomiędzy obowiązującymi systemami wartościowymi warto określić zakres podmiotowy i przedmiotowy systemu. Podmiotami opodatkowania są właściciele lub użytkownicy danej nieruchomości. Co do zakresu przedmiotowego, można spotkać dwa rozwiązania [Felis 2013]:

- stosowanie jednego rodzaju podatku o szerokim zakresie przedmiotowym,

- wprowadzenie kilku rodzajów danin, które dotyczą poszczególnych typów nieruchomości.

Pierwsze rozwiązanie obowiązuje w większości państw członkowskich UE, które stosują system wartościowy. Niemniej jednak w państwach takich jak Francja, Wielka Brytania czy też Dania system wartościowy został podzielony w zależności od rodzaju nieruchomości objętej podatkiem majątkowym.

Warto zatem przybliżyć rodzaje systemów wartościowych stosowanych w wybranych państwach członkowskich UE. W tabeli 1 przedstawiono różne ujęcia podstaw opodatkowania, zakresu przedmiotowego i podmiotowego oraz krótką charakterystykę stosowanych systemów. 
Tabela 1. Podstawa opodatkowania i charakterystyka podatku od nieruchomości w wybranych państwach członkowskich UE

\begin{tabular}{|c|c|c|c|}
\hline Państwo & $\begin{array}{c}\text { System } \\
\text { opodatkowania }\end{array}$ & Podstawa opodatkowania & $\begin{array}{c}\text { Charakterystyka } \\
\text { (wybrane elementy) }\end{array}$ \\
\hline 1 & 2 & 3 & 4 \\
\hline Austria & Wartościowy & $\begin{array}{l}\text { Wartość jednostkowa } \\
\text { nieruchomości szacowana } \\
\text { na podstawie przepisów } \\
\text { ustawy o ustaleniu } \\
\text { wartości. Oszacowanie } \\
\text { wartości uwzględnia } \\
\text { rodzaj nieruchomości oraz } \\
\text { przeznaczenie. }\end{array}$ & $\begin{array}{l}\text { Ustawowe stawki podatku od } \\
\text { nieruchomości: od } 0,05 \% \text { do } 0,2 \% \\
\text { dla nieruchomości zabudowanych. } \\
\text { Maksymalna stawka ustalona przez } \\
\text { gminy może być } 4,2 \text { razy wyższa. }\end{array}$ \\
\hline Belgia & Wartościowy & $\begin{array}{l}\text { Wartość rocznego czynszu } \\
\text { jako procent } \mathrm{z} \text { dochodu, jaki } \\
\text { hipotetycznie nieruchomość } \\
\text { może zapewnić } \\
\text { właścicielowi. }\end{array}$ & $\begin{array}{l}\text { Wysokość podatku zależy od } \\
\text { lokalizacji nieruchomości: } \\
\text { region flamandzki: } 2,50 \% \text {, } \\
\text { region waloński: } 1,25 \% \text {, } \\
\text { Bruksela: } 2,25 \% \text {. }\end{array}$ \\
\hline Dania & Wartościowy & \begin{tabular}{|l|} 
Wartość gruntu, nie \\
wliczając wartości budynku. \\
Uwzględnione są również \\
ulepszenia, np.: kanalizacja, \\
drogi, które później podlegają \\
odliczeniu od wartości przez \\
kolejnych 30 lat.
\end{tabular} & $\begin{array}{l}\text { Wysokość podatku różni się } \\
\text { w zależności od regionu, aczkolwiek } \\
\text { oscyluje od } 1,6 \text { do } 3,4 \% \text { wartości } \\
\text { nieruchomości. }\end{array}$ \\
\hline Finlandia & Wartościowy & $\begin{array}{l}\text { Wartość nieruchomości } \\
\text { wynikająca z katastru. }\end{array}$ & $\begin{array}{l}\text { Wysokość podatku od nieruchomości } \\
\text { zawiera się w przedziale od } 0,41 \\
\text { do } 6 \% \text { wartości nieruchomości. }\end{array}$ \\
\hline Francja & Wartościowy & $\begin{array}{l}\text { Wartość czynszowa } \\
\text { przedstawiająca najbardziej } \\
\text { prawdopodobny dochód } \\
\text { z tytułu jej wynajęcia } \\
\text { w normalnych warunkach. }\end{array}$ & $\begin{array}{l}\text { Właściciel nieruchomości jest } \\
\text { podmiotem opodatkowania. Istnieją } \\
\text { jednak przypadki, w których } \\
\text { podatnikiem jest władający } \\
\text { (dzierżawa, użytkowanie wieczyste). } \\
\text { System przewiduje tzw. wakacje } \\
\text { podatkowe dla nowo wybudowanych } \\
\text { nieruchomości pod wynajem. }\end{array}$ \\
\hline Niemcy & Wartościowy & $\begin{array}{l}\text { Wartość rynkowa } \\
\text { nieruchomości szacowana } \\
\text { na podstawie wskaźnika } \\
\text { wyrażonego procentowo. } \\
\text { Dla gruntów zabudowanych } \\
\text { i budynków mieszkalnych } \\
\text { wartość rynkową szacuje } \\
\text { się na podstawie wartości } \\
\text { czynszowej. }\end{array}$ & $\begin{array}{l}\text { Właściciel nieruchomości jest } \\
\text { podmiotem opodatkowania. } \\
\text { Stawka podatkowa wynosi od } 0,26 \\
\text { do } 1 \% \text { w zależności od landu. }\end{array}$ \\
\hline
\end{tabular}


Tabela 1, cd.

\begin{tabular}{|c|c|c|c|}
\hline 1 & 2 & 3 & 4 \\
\hline Polska & Powierzchniowy & $\begin{array}{l}\text { Powierzchnia użytkowa } \\
\text { mierzona } \mathrm{w} \mathrm{m}^{2} \text {. }\end{array}$ & $\begin{array}{l}\text { Maksymalne wysokości stawek } \\
\text { podatkowych ustala co roku } \\
\text { Minister Finansów. Rada gminy } \\
\text { w drodze uchwały rokrocznie ustala } \\
\text { wysokość stawek podatkowych } \\
\text { nieprzekraczających stawek } \\
\text { maksymalnych. } \\
\text { Stawki maksymalne w } 2018 \mathrm{r} \text {. } \\
\text { zawierają się w przedziale od } 0,48 \text { do } \\
\text { nawet } 23,10 \mathrm{zt} / \mathrm{m}^{2} \text {. }\end{array}$ \\
\hline Słowacja & Powierzchniowy & $\begin{array}{l}\text { Powierzchnia użytkowa } \\
\text { mierzona } \mathrm{w} \mathrm{m}^{2} \text {. }\end{array}$ & $\begin{array}{l}\text { Stawka podatkowa podatku od } \\
\text { budynków wynosi od } 0,033 \text { do } 0,30 \\
\text { euro } / \mathrm{m}^{2} \text {. }\end{array}$ \\
\hline Szwecja & Wartościowy & $\begin{array}{l}\text { Podstawą opodatkowania } \\
\text { jest około } 75 \% \text { wartości } \\
\text { rynkowej nieruchomości. }\end{array}$ & $\begin{array}{l}\text { Opodatkowaniu nie podlegają } \\
\text { grunty rolne, leśne oraz budynki } \\
\text { gospodarcze. } \\
\text { Stawki podatkowe wynoszą od } 0,5 \\
\text { do } 1,7 \% \text {. }\end{array}$ \\
\hline Węgry & Mieszany & $\begin{array}{l}\text { Powierzchnia użytkowa lub } \\
\text { wartość. }\end{array}$ & $\begin{array}{l}\text { Podmiotem opodatkowania jest } \\
\text { właściciel nieruchomości. } \\
\text { Stawka podatkowa zależy od } \\
\text { lokalizacji przedmiotu opodatkowania } \\
\text { i wynosi średnio } 3 \text { euro/m² lub } \\
\text { maksymalnie } 3 \% \text { wartości rynkowej } \\
\text { nieruchomości. }\end{array}$ \\
\hline $\begin{array}{l}\text { Wielka } \\
\text { Brytania }\end{array}$ & Wartościowy & $\begin{array}{l}\text { Oszacowana wartość } \\
\text { nieruchomości, która } \\
\text { w głównej mierze zależy } \\
\text { od lokalizacji. Stawka } \\
\text { podatkowa zależy także od } \\
\text { klasyfikacji nieruchomości } \\
\text { w jednym z ośmiu } \\
\text { przedziałów wartości (A-H). }\end{array}$ & $\begin{array}{l}\text { Podmiotem opodatkowania jest osoba } \\
\text { fizyczna, która ukończyła } 18 \text { rok } \\
\text { życia i jest wyłącznym lub głównym } \\
\text { mieszkańcem opodatkowanej } \\
\text { nieruchomości. } \\
\text { Brytyjski system opodatkowania } \\
\text { rozróżnia dwa podatki: Council Tax } \\
\text { dla nieruchomości przeznaczonych do } \\
\text { zamieszkania oraz Non-domestic Rate } \\
\text { dla nieruchomości niemieszkalnych. }\end{array}$ \\
\hline
\end{tabular}

Źródło: opracowanie własne na podstawie [Kopczyk 2016; Obwieszczenie MRiF 2017; http://www. exportenterprises.bcsgunternehmerportal.com/pl/informacje-o-rynku/norwegia/podatki; http:// www.globalpropertyguide.com/Europe/Belgium/Taxes-and-Costs; http://www.globalpropertyguide.com/Europe/Finland/Taxes-and-Costs; http:/www.gtai.de/GTAI/Navigation/EN/Invest/Investment-guide/The-tax-system/taxation-of-property.html; http://www.mojanorwegia. $\mathrm{pl} /$ biznes-i-gospodarka/oslo-ujawnia-dane-o-podatku-od-nieruchomosci-każdy-sprawdzi-ileplaci-sasiad-11584.html]. 


\section{Znaczenie podatku od nieruchomości w dochodach podatkowych}

Współczesny system opodatkowania nieruchomości UE tworzy 28 niezależnych systemów państw członkowskich. Podsumowując wcześniejsze rozważania, można zauważyć, iż nie istnieją dwa identyczne systemy opodatkowania nieruchomości.

Na postawie badania udziału podatku od nieruchomości w dochodach podatkowych ogółem można jednoznacznie stwierdzić, iż krajem przodującym jest Wielka Brytania, której dochody z tytułu podatku od nieruchomości oscylują między 9,2 a 9,5\%. Na drugim miejscu jest Francja (7-6,8\%). Polska na tle państw członkowskich UE znajduje się w pierwszej piątce państw osiągających jedne z najwyższych dochodów z podatku od nieruchomości w stosunku do dochodów podatkowych ogółem, a najwyższe wśród państw stosujących system powierzchniowy opodatkowania nieruchomości. Najniższe dochody zaś osiągają Chorwacja $(0,1 \%)$ i Luksemburg $(0,2 \%)$. Malta nie osiąga dochodów z tytułu podatku od nieruchomości, bowiem go nie stosuje (tab. 2).

Tabela 2. Udział procentowy podatku od nieruchomości w dochodach podatkowych ogółem w państwach członkowskich UE latach 2010-2015

\begin{tabular}{|l|l|l|l|l|r|r|c|}
\hline \multicolumn{1}{|c|}{ Państwo } & 2010 & 2011 & 2012 & 2013 & 2014 & 2015 & Dynamika 2010=100\% \\
\hline Belgia & 2 & 3 & 4 & 5 & 6 & 7 & 8 \\
\hline Bułgaria & 2,9 & 2,9 & 2,8 & 2,9 & 2,9 & 2,9 & 100 \\
\hline Czechy & 1 & 1,1 & 1,1 & 1,1 & 1,1 & 1,1 & 110 \\
\hline Dania & 0,7 & 0,6 & 0,7 & 0,7 & 0,7 & 0,7 & 100 \\
\hline Niemcy & 4,5 & 4,5 & 4,4 & 4,4 & 4,2 & 4,4 & 98 \\
\hline Estonia & 1,2 & 1,2 & 1,2 & 1,1 & 1,1 & 1,1 & 92 \\
\hline Irlandia & 2,8 & 1 & 1 & 1 & 0,9 & 0,8 & 80 \\
\hline Grecja & 3,2 & 5,8 & 3 & 3,3 & 3,4 & 2,9 & 104 \\
\hline Hiszpania & 3 & 3,2 & 3,5 & 3,7 & 3,8 & 3,7 & 231 \\
\hline Francja & 6,8 & 7 & 6,9 & 6,9 & 6,9 & 7 & 123 \\
\hline Chorwacja & 0,1 & 0,1 & 0,1 & 0,1 & 0,1 & 0,1 & 103 \\
\hline Włochy & 1,5 & 1,6 & 3,6 & 3,2 & 3,8 & 3,9 & 100 \\
\hline Cypr & 3 & 2,6 & 2,4 & 3,6 & 3,5 & 3,6 & 260 \\
\hline Łotwa & 2,5 & 2,8 & 2,7 & 2,7 & 2,8 & 2,8 & 120 \\
\hline Litwa & 1,3 & 1,1 & 1 & 1 & 1,1 & 1,2 & 112 \\
\hline Luksemburg & 0,2 & 0,2 & 0,2 & 0,2 & 0,2 & 0,2 & 92 \\
\hline Węgry & 0,8 & 0,9 & 1 & 1,5 & 1,4 & 1,4 & 100 \\
\hline Malta & 0 & 0 & 0 & 0 & 0 & 0 & 175 \\
\hline
\end{tabular}


Tabela 2, cd.

\begin{tabular}{|l|c|c|c|c|c|c|c|}
\hline \multicolumn{1}{|c|}{1} & 2 & 3 & 4 & 5 & 6 & 7 & 8 \\
\hline Holandia & 1,7 & 1,7 & 1,8 & 2 & 2,4 & 2,3 & 135 \\
\hline Austria & 0,5 & 0,5 & 0,5 & 0,5 & 0,5 & 0,5 & 100 \\
\hline Polska & 3,6 & 3,5 & 3,7 & 3,9 & 3,9 & 3,8 & 106 \\
\hline Portugalia & 2 & 2,1 & 2,1 & 2,3 & 2,4 & 2,4 & 120 \\
\hline Rumunia & 2,5 & 2,3 & 2,3 & 2,3 & 2,3 & 2,2 & 88 \\
\hline Słowenia & 1,3 & 1,3 & 1,4 & 1,5 & 1,4 & 1,4 & 108 \\
\hline Słowacja & 1,5 & 1,4 & 1,5 & 1,5 & 1,4 & 1,3 & 87 \\
\hline Finlandia & 1,5 & 1,4 & 1,5 & 1,5 & 1,7 & 1,7 & 113 \\
\hline Szwecja & 1,7 & 1,7 & 1,8 & 2 & 1,9 & 1,9 & 112 \\
\hline Wielka Brytania & 9,4 & 9,2 & 9,4 & 9,5 & 9,4 & 9,2 & 98 \\
\hline
\end{tabular}

Źródło: opracowanie własne na podstawie [Taxation Trends in the European Union ... 2017].

Dokonując analizy dynamiki podatku pod nieruchomości w dochodach podatkowych ogólem i porównując rok 2015 do roku bazowego 2010, można stwierdzić, że najwyższą dynamikę wzrostową osiągnęły Włochy, gdzie udział ten zwiększył się 2,6-krotnie. Wzrost ten był spowodowany wprowadzeniem reformy opodatkowania majątku nieruchomego w 2012 roku, którą objęto wszystkie nieruchomości bez względu na to, czy są zamieszkane, czy też nie. Drugą co do wielkości dynamiką cechowała się Grecja (2,31-krotny wzrost), która zwiększenie udziału podatku od nieruchomości w dochodach podatkowych ogółem również zawdzięcza reformie podatkowej z 2011 roku, która obowiązkiem podatkowym objęła rolników niebędących wcześniej podatnikami podatku od nieruchomości. Największy spadek wystąpił w Estonii, gdzie udział tego podatku w 2015 roku wyniósł 80\% w porównaniu do roku 2010.

Analizując średni udział podatku od nieruchomości we wszystkich podatkach państw członkowskich UE przy uwzględnieniu podziału systemów opodatkowania nieruchomości, zauważa się, że system wartościowy znacząco odbiega od pozostałych, a nawet od średniej państw (rys. 2). Co więcej, system wartościowy jako jedyny charakteryzuje się trendem rosnącym przez cały okres badawczy. Niemniej jednak cechą wspólną jest spowolnienie przyrostu udziału podatku od nieruchomości we wszystkich podatkach od 2013 roku, a dla systemu powierzchniowego i mieszanego odnotowano delikatny spadek.

Porównując system powierzchniowy z systemem mieszanym, można zauważyć, że występują tutaj jedynie nieznaczne wahania.

Analizując rozpiętość różnic średnich udziałów podatku od nieruchomości we wszystkich dochodach podatkowych, można zauważyć, iż dysproporcje pomiędzy systemem wartościowym a powierzchniowym zwiększają się rokrocznie. Początkowo w 2010 roku różnica ta wynosi 31\%, a w 2015 roku osiąga już ponad 40\%. Podobny trend występuje w relacji systemu wartościowego z mieszanym. 


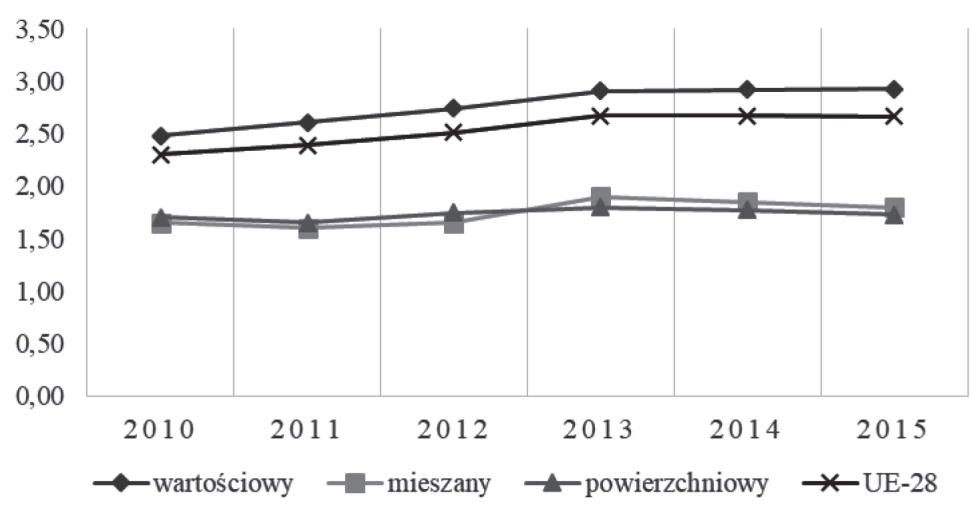

Rys. 2. Średni udział (w \%) podatku od nieruchomości w dochodach podatkowych ogółem w państwach członkowskich UE w latach 2010-2015

Źródło: opracowanie własne na podstawie [Taxation Trends in the European Union ... 2017].

\section{Relacja podatku od nieruchomości do PKB}

Analizując relację podatku od nieruchomości do PKB, można zauważyć, że wskaźnik osiąga różne wartości dla poszczególnych krajów, począwszy od najwyższego dla Wielkiej Brytanii $(3,1 \%)$ do najniższego dla Luksemburga $(0,1 \%)$. Na przestrzeni lat odnotowuje się zarówno wzrost wskaźnika w poszczególnych państwach, jak i spadek. Jak wynika $z$ danych zawartych $w$ tab. 3, stopniowy wzrost odnotowano w państwach, gdzie poziom wskaźnika jest znaczący: Dania, Francja oraz Wielka Brytania. Niemniej jednak ta sama tendencja zauważalna jest w krajach o niskim poziomie wskaźnika: Bułgaria, Finlandia, Portugalia czy Rumunia. Ponadto można dostrzec trend spadkowy w Szwecji, Włoszech czy Holandii. W przypadku Chorwacji i Malty badany wskaźnik osiąga wartość zero. W obu państwach obowiązek podatkowy występuje w przypadku sprzedaży, darowizny, spadku lub wynajmu nieruchomości np. na cele turystyczne [http://www.realestatecroatiaistria.com/property-taxes-in-croatia.aspx (10.03.2018)]. Pozostałe państwa członkowskie odznaczają się niewielkimi wzrostami i spadkami, które występują naprzemiennie.

W państwach, w których obowiązuje system powierzchniowy, odnotowuje się niski procentowy udział podatku od nieruchomości w PKB. Wyjątek tu stanowi Polska (1,1-1,3\%), która znacząco odbiega od pozostałych państw stosujących system powierzchniowy, gdyż najwyższe dochody z tytułu podatku od nieruchomości stanowią nieruchomości przeznaczone na działalność gospodarczą, dla których przewidziano najwyższe stawki kwotowe.

Analizując dynamikę pomiędzy pierwszym i ostatnim rokiem uwzględnionym w badaniu, można zauważyć, iż najwyższy wzrost udziału podatku od nieruchomości w PKB odnotowano we Włoszech $(2,83)$, drugi z kolei wysoki wskaźnik osiąg- 
nęła Grecja (2,7), a następnie Węgry $(2,0)$. W Czechach, Estonii i Niemczech nie odnotowano zmian.

Tabela 3. Udział procentowy podatku od nieruchomości w PKB w państwach członkowskich UE w latach 2010-2015

\begin{tabular}{|c|c|c|c|c|c|c|c|}
\hline Państwo & 2010 & 2011 & 2012 & 2013 & 2014 & 2015 & $\begin{array}{c}\text { Dynamika } \\
2010 / 2015 \\
2010=100 \%\end{array}$ \\
\hline Belgia & 1,3 & 1,3 & 1,3 & 1,3 & 1,3 & 1,3 & 100 \\
\hline Bułgaria & 0,3 & 0,3 & 0,3 & 0,3 & 0,3 & 0,3 & 100 \\
\hline Czechy & 0,2 & 0,2 & 0,2 & 0,2 & 0,2 & 0,2 & 100 \\
\hline Dania & 2 & 2 & 2 & 2,1 & 2,1 & 2,1 & 105 \\
\hline Niemcy & 0,4 & 0,4 & 0,4 & 0,4 & 0,4 & 0,4 & 0 \\
\hline Estonia & 0,3 & 0,3 & 0,3 & 0,3 & 0,3 & 0,3 & 0 \\
\hline Irlandia & 0,8 & 0,8 & 0,8 & 1 & 1 & 0,7 & 88 \\
\hline Grecja & 1 & 1,9 & 2,2 & 2,7 & 2,5 & 2,7 & 270 \\
\hline Hiszpania & 1 & 1 & 1,1 & 1,2 & 1,3 & 1,3 & 130 \\
\hline Francja & 2,9 & 3 & 3,1 & 3,1 & 3,2 & 3,2 & 110 \\
\hline Chorwacja & 0 & 0 & 0 & 0 & 0 & 0 & - \\
\hline Włochy & 0,6 & 0,6 & 1,5 & 1,4 & 1,7 & 1,7 & 283 \\
\hline Cypr & 1 & 0,8 & 0,8 & 1,1 & 1,2 & 1,2 & 120 \\
\hline Łotwa & 0,7 & 0,8 & 0,8 & 0,8 & 0,8 & 0,8 & 114 \\
\hline Litwa & 0,4 & 0,3 & 0,3 & 0,3 & 0,3 & 0,3 & 75 \\
\hline Luksemburg & 0,1 & 0,1 & 0,1 & 0,1 & 0,1 & 0,1 & 100 \\
\hline Węgry & 0,3 & 0,3 & 0,4 & 0,6 & 0,5 & 0,6 & 200 \\
\hline Malta & 0 & 0 & 0 & 0 & 0 & 0 & - \\
\hline Holandia & 0,6 & 0,6 & 0,6 & 0,7 & 0,9 & 0,9 & 150 \\
\hline Austria & 0,2 & 0,2 & 0,2 & 0,2 & 0,2 & 0,2 & 100 \\
\hline Polska & 1,1 & 1,1 & 1,2 & 1,3 & 1,2 & 1,2 & 109 \\
\hline Portugalia & 0,6 & 0,7 & 0,7 & 0,8 & 0,8 & 0,8 & 133 \\
\hline Rumunia & 0,7 & 0,7 & 0,6 & 0,6 & 0,6 & 0,6 & 86 \\
\hline Słowenia & 0,5 & 0,5 & 0,5 & 0,6 & 0,5 & 0,5 & 100 \\
\hline Słowacja & 0,4 & 0,4 & 0,4 & 0,4 & 0,4 & 0,4 & 100 \\
\hline Finlandia & 0,6 & 0,6 & 0,6 & 0,7 & 0,7 & 0,8 & 133 \\
\hline Szwecja & 0,7 & 0,7 & 0,8 & 0,8 & 0,8 & 0,8 & 114 \\
\hline Wielka Brytania & 3,2 & 3,1 & 3,2 & 3,1 & 3,1 & 3,1 & 97 \\
\hline
\end{tabular}

Źródło: opracowanie własne na podstawie [Taxation Trends in the European Union ... 2017]. 


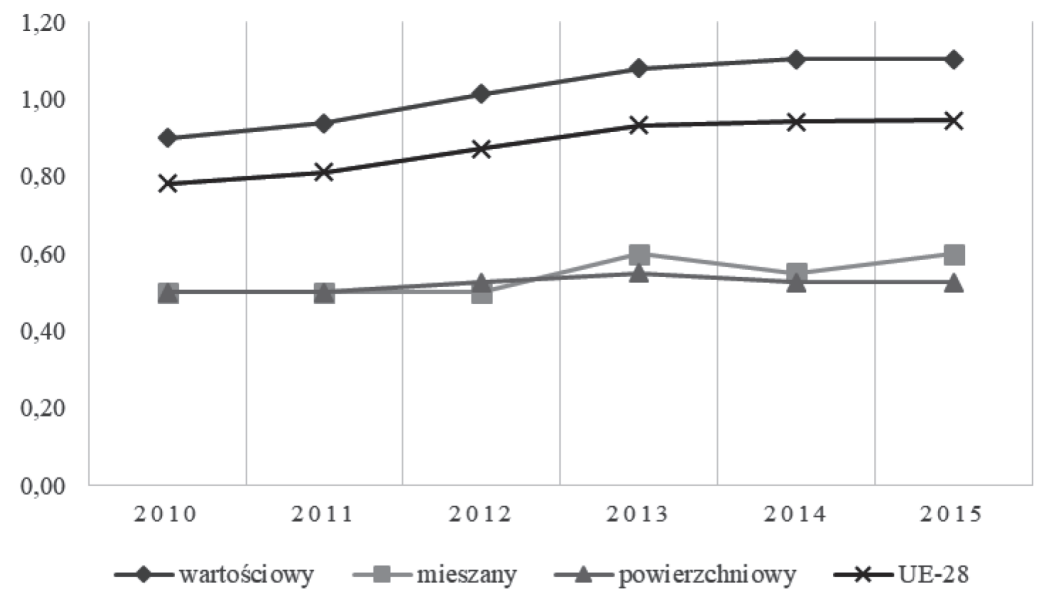

Rys. 3. Średni udział (w \%) podatku od nieruchomości w PKB w państwach członkowskich UE Źródło: opracowanie własne na podstawie [Taxation Trends in the European Union ... 2017].

Badając średni udział podatku od nieruchomości w PKB państw członkowskich UE, można zauważyć, że najbardziej stabilny udział podatku występuje w tych państwach, które stosują system powierzchniowy. Udział ten w okresie badawczym nie ulega gwałtownym fluktuacjom (rys. 3).

Dysproporcje pomiędzy średnimi udziałami podatku od nieruchomości w PKB w zależności od stosowanego systemu opodatkowania nieruchomości są znaczne, gdyż prawie dwukrotnie wyższe dochody uzyskują państwa stosujące system wartościowy.

\section{Podsumowanie}

Na podstawie przeprowadzonych analiz można jednoznacznie stwierdzić, że podatek od nieruchomości jest stabilnym źródłem dochodu niezależnie od przyjętego systemu opodatkowania nieruchomości, gdyż ulega tylko znikomym wahaniom. Należy zaznaczyć, że stabilność ta jest większa w systemach powierzchniowych, gdzie zmienna może być jedynie stawka opodatkowania, a powierzchnia nieruchomości pozostaje niezmienna.

W systemach ad valorem zarówno stawka opodatkowania, jak i wartość podstawy opodatkowania ulegają zmianie. Systemy te są zatem bardziej wrażliwe na wahania majętności społeczeństwa, sytuację gospodarczą, a co za tym idzie, na fiskalne czynniki opodatkowania.

Wielkość wpływów z tytułu podatku od nieruchomości zależy od stosowanego przez państwo systemu opodatkowania. Państwa stosują tu odmienną strategię struktury podatku, począwszy od Malty, która nie pobiera podatków od nieruchomości, 
po Grecję, gdzie udział tych podatków w dochodach ogółem oscyluje w okolicach 7\%. Główną przyczyną takich zachowań jest osiągnięcie odpowiedniej wydajności fiskalnej w celu pokrycia głównych wydatków publicznych.

\section{Literatura}

Etel L., 2003, Europejskie systemy opodatkowania nieruchomości, Wydawnictwo Sejmowe, Warszawa. Famulska T. (red.), 2009, Dochody podatkowe jednostek samorządu terytorialnego w krajach UE, Wydawnictwo Akademii Ekonomicznej w Katowicach, Katowice.

Felis P., 2013, Podatek od nieruchomości w Europie, Biuro Analiz Sejmowych, nr 1 (138).

Głuszak M., Marona B., 2015, Podatek katastralny: ekonomiczne uwarunkowania reformy opodatkowania nieruchomości, Poltext, Warszawa.

http://www.cfe-eutax.org (03.01.2018).

http://www.exportenterprises.bcsgunternehmerportal.com/pl/informacje-o-rynku/norwegia/podatki (03.01.2018).

http://www.globalpropertyguide.com/Europe/Belgium/Taxes-and-Costs

http://www.globalpropertyguide.com/Europe/Finland/Taxes-and-Costs (10.03.2018).

http:/www.gtai.de/GTAI/Navigation/EN/Invest/Investment-guide/The-tax-system/taxation-of-property.html (10.03.2018).

http://www.mojanorwegia.pl/biznes-i-gospodarka/oslo-ujawnia-dane-o-podatku-od-nieruchomoscikażdy-sprawdzi-ile-placi-sasiad-11584.html (10.03.2018).

$\mathrm{http} / / / \mathrm{www} \cdot$ realestatecroatiaistria.com/property-taxes-in-croatia.aspx (10.03.2018).

Kopczyk A., 2016, Warunki życia i pracy w krajach Europejskiego Obszaru Gospodarczego, Ministerstwo Rodziny Pracy i Polityki Społecznej, Departament Rynku Pracy, Warszawa.

Marona B., 2006, System opodatkowania nieruchomości w Polsce na tle rozwiazań w wybranych krajach europejskich, Zeszyty Naukowe Akademii Ekonomicznej w Krakowie nr 703, Kraków.

Obwieszczenie Ministra Rozwoju i Finansów z dnia 28 lipca 2017 r. w sprawie górnych granic stawek kwotowych podatków i opłat lokalnych w 2018 r. Dz. Urz. RP z dnia 9 sierpnia 2017, poz. 800.

Taxation Trends in the European Union. Data for EU member states, Iceland and Norway, Eurostat, European Commission, Luxembourg 2017.

Ustawa z dnia 12 stycznia 1991 r. o podatkach i opłatach lokalnych, Dz.U. 2017, poz. 1785, 2141, $2372,2432$. 